\title{
New dental material and redescription of Agerinia roselli (Primates, Adapiformes) from Les Saleres (early Eocene, NE Iberian Peninsula)
}

\author{
Joan Femenias-Gual, Raef Minwer-Barakat, Judit Marigó, and Salvador Moyà-Solà
}

\begin{abstract}
In this work, new dental material of Agerinia roselli from its type locality, Les Saleres (NE Spain), is described. An emended diagnosis of the species is provided, together with a redescription of the entire hypodigm from that locality, which was necessary due to some inaccuracies in previous descriptions. The studied material includes 12 teeth (from $P_{3}$ to $M_{3}$ ); the roots of the anterior premolars preserved in a mandible fragment are reported for the first time. Some previously undescribed traits have been identified after the new analysis of this material, such as the $\mathrm{P}_{4}$ with distinct hypoconid and entoconid and the tiny paraconid on the $\mathrm{M}_{1}$. A detailed comparison with other cercamoniines has been made. The body mass of $A$. roselli, ranging from 650 to $900 \mathrm{~g}$, has also been estimated.

The presence of a minuscule paraconid in the $M_{1}$ is the most reliable criterion for distinguishing this molar from the $M_{2}$. This is supported by the complete absence of paraconid in four $\mathrm{M}_{2}$ preserved in mandible fragments. The trigonid length seems to be less reliable for distinguishing $M_{1}$ from $M_{2}$, due to its high variability in this species. Concluding, this study updates the knowledge about the dental anatomy of $A$. roselli and demonstrates that it is a valid taxon clearly distinguishable from other cercamoniines.
\end{abstract}

Joan Femenias-Gual. Institut Català de Paleontologia Miquel Crusafont, Universitat Autònoma de Barcelona, 08193 Cerdanyola del Vallès, Barcelona, Spain. joan.femenias@icp.cat

Raef Minwer-Barakat. Institut Català de Paleontologia Miquel Crusafont, Universitat Autònoma de Barcelona, 08193 Cerdanyola del Vallès, Barcelona, Spain. raef.minwer@icp.cat Judit Marigó. UMR 7207 CR2P - C.N.R.S., M.N.H.N., U.P.M.C.-Paris6. Département Histoire de la Terre, Muséum National d'Histoire Naturelle, Paris, France. judit.marigo@mnhn.fr

Salvador Moyà-Solà. ICREA at Institut Català de Paleontologia Miquel Crusafont, Universitat Autònoma de Barcelona, 08193 Cerdanyola del Vallès, Barcelona, Spain. salvador.moya@icp.cat.

Keywords: Adapiformes; Notharctidae; Cercamoniinae; Paleogene; Spain

Submission: 17 November 2015 Acceptance:22 April 2016

Femenias-Gual, Joan, Minwer-Barakat, Raef, Marigó, Judit, and Moyà-Solà, Salvador. 2016. New dental material and redescription of Agerinia roselli (Primates, Adapiformes) from Les Saleres (early Eocene, NE Iberian Peninsula). Palaeontologia Electronica 19.2.17A: 1-17 palaeo-electronica.org/content/2016/1468-redescription-of-a-roselli 


\section{INTRODUCTION}

The early Eocene recorded an important step in the early diversification of primates. The primate record in Europe at this time is not very abundant, although rather diverse and geographically widespread (e.g., Russell et al., 1967; Godinot, 1978, 1981; Franzen, 1987, 2000a; Marandat, 1991; Estravís, 2000; Smith et al., 2006; Franzen et al., 2009; Gebo et al., 2012, 2015; Hooker, 2012; Marigó et al., 2012, 2014). In the Iberian Peninsula, the first studies of Eocene primates were undertaken in the 1960s (Crusafont-Pairó, 1967). In the last decade, the research team of the Institut Català de Paleontologia Miquel Crusafont (ICP) has restarted the study of the Paleogene primate record from Spain, but focusing on middle and late Eocene sites (Minwer-Barakat et al., 2010, 2012, 2013a, 2013b, 2015a, 2015b), including the definition of several new anchomomyins (Marigó et al., 2010, 2011, 2013) and the first interpretations about their locomotion (Marigó et al., 2016). On the contrary, recent studies of early Eocene primates from the Iberian Peninsula only involve some preliminary studies of Euprimates (Femenias-Gual et al., 2014, 2015) and the description of Arcius from Masia de l'Hereuet, the first record of Plesiadapiformes from Spain (Marigó et al., 2012). For this reason, the revision of classical material is essential in order to improve the knowledge of the primates from this time span.

Crusafont-Pairó (1967) first described an early Eocene primate from the Iberian Peninsula, Agerinia roselli. Since then, the paucity of material and the lack of detailed descriptions and high quality images have complicated the comparison of this species with other taxa. Moreover, the exact geographic location of the type locality Les Saleres is unknown, preventing the collection of further material. Furthermore, this species and Donrussellia lusitanica are the only euprimates determined at the specific level in the early Eocene from the Iberian Peninsula. For all these reasons, the redescription of this species is absolutely necessary.

The species, originally named as Agerina roselli, was described on the basis of two mandible fragments with $M_{2}$ and $M_{3}$, as well as three isolated teeth, either $M_{1}$ or $M_{2}$ (Crusafont-Pairó, 1967). Later on, Crusafont-Pairó (1973) changed the generic name into Agerinia, because the original name was preoccupied by a genus of trilobites. Szalay (1971) gave more accurate descriptions of the material from Les Saleres, including most (but not all) of the remains described by CrusafontPairó (1967) and another previously unpublished specimen from the same locality (a mandible fragment with $\mathrm{P}_{3}-\mathrm{P}_{4}$ ). Szalay (1971) also provided a first diagnosis for this species, since the original description by Crusafont did not include a proper diagnosis, but only a short description of the material. Crusafont-Pairó and Golpe-Posse (1975) reported a supposed upper molar of $A$. roselli from Les Saleres, but after direct observation of this specimen (IPS-36182), housed in the ICP, it has been proved to belong to an artiodactyl. Therefore, the upper dentition of $A$. roselli remains unknown. Agerinia was synonymized with Periconodon by Gingerich (1976, 1977), but Szalay and Delson (1979) and Godinot (1988) considered Agerinia as a valid genus. Regarding its suprageneric placement, Agerinia was tentatively included in the Necrolemuridae by Crusafont-Pairó (1967). However, it was later relocated within the Adapidae by Szalay (1971) and Szalay and Delson (1979), due to its similarities with Protoadapis, Pelycodus and Pronycticebus. Later, Godinot (1998) included this genus in a new subfamily, Pronycticebinae, within an "incertae sedis" family of Adapiformes. Recent works place Agerinia in the subfamily Cercamoniinae (Gebo, 2002; Godinot, 2015).

Recently, during the revision of the classical collection from Les Saleres stored in the ICP, more unpublished dental specimens of $A$. roselli have been found, including three complete and one incomplete lower molars. In this work, a detailed description of all the available dental material of Agerinia roselli from Les Saleres is provided for the first time, including both unpublished and previously published specimens, together with accurate measurements and high quality images. It is further presented an emended diagnosis of this species that emphasizes and discusses some morphological features not observed before, such as the roots of the mesial premolars interpreted on the basis of the root fragments preserved in one of the available mandibles. In addition, the body mass of $A$. roselli is estimated based on the size of the $\mathrm{M}_{1}$ and $\mathrm{M}_{2}$. Finally, the material of $A$. roselli from Les Saleres is compared with other samples ascribed to Agerinia, as well as with other Eurasian adapiformes, thus improving the knowledge about this still poorly known primate genus.

\section{Geographical, Geological, and Biochronological Context}

The exact geographic location of Les Saleres, the type locality of Agerinia roselli, is unknown. However, Crusafont-Pairó and Rosell-Sanuy (1966) stated that it was close to the small town 


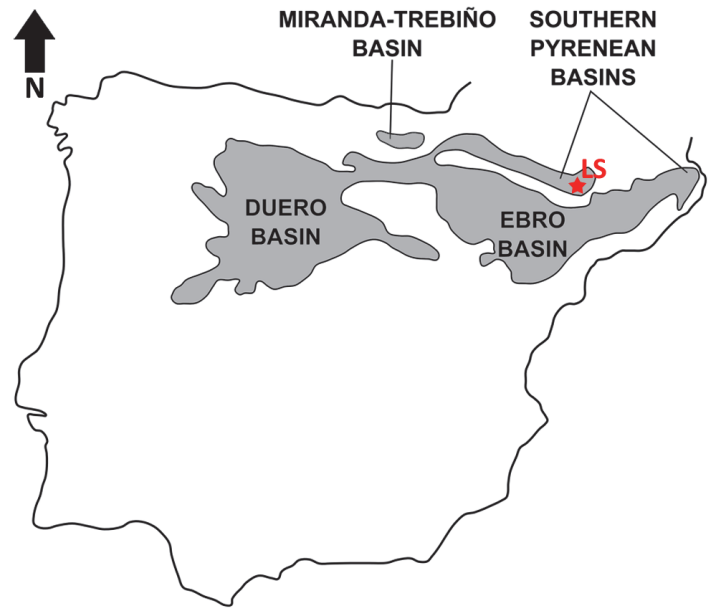

FIGURE 1. Map showing the main Tertiary basins of the Iberian Peninsula with the location of Les Saleres (LS) fossil site (modified from Antunes et al., 1997).

called L'Ametlla del Montsec, in the eastern sector of the Àger valley (La Noguera, Lleida province, NE Spain). Geologically, this fossil site is placed in the Àger sub-basin, within the Southern Pyrenean Basins (Figure 1). The continental Eocene deposits of this sub-basin were first studied by CrusafontPairó and Rosell-Sanuy (1966) and later by RosellSanuy and Llompart-Díaz (1988), Checa (1995), and Badiola et al. (2009). Its infill mainly consists of marls, clays and sandstones, with conglomeratic levels in several areas. The sandstones are associated with complex channels of braided rivers, whereas the marls and clays correspond to floodplain deposits. Scarce and generally dispersed fossil remains of mammals, crocodiles and turtles have been found in these deposits.

Regarding the age of this fossil site, Les Saleres was assigned to the late early Eocene by Crusafont-Pairó (1967) and Szalay (1971). Later, Antunes et al. (1997) provided a faunal list for this locality and ascribed it to the MP10 Mammal Paleogene Reference Level. However, the mammal assemblage listed by Antunes et al. (1997) presents clear inconsistencies. On the one hand, the perissodactyl Lophiaspis maurettei is present in other European localities such as Palette (MP7; Godinot et al., 1987), Silveirinha (MP7; Estravís, 2000) and Mutigny (MP8/9; Hooker, 1996), thus suggesting for Les Saleres an age older than MP10. But, on the other hand, other taxa presumably identified in Les Saleres are recorded in much younger localities. This is the case of the artiodactyl Cebochoerus, present in middle and late Eocene fossil sites like Eckfeld Maar (MP13),
Robiac (MP16), Fons 4, Sossís (MP17a) or La Débruge (MP18), and the carnivore Cynodictis, recognized in even younger localities such as $\mathrm{La}$ Débruge and Escamps (MP19) (BiochroM'97, 1997; Franzen, 2004; Minwer-Barakat et al., $2015 \mathrm{~b}$, among others). Some of the taxonomic determinations of the material from Les Saleres seem to be incorrect, so the fauna from that site claims for a careful revision and, consequently, the age proposed by Antunes et al. (1997) cannot be considered conclusive. In any case, although a detailed dating cannot be provided, Les Saleres can be confidently assigned to the early Eocene, which is the age of the continental deposits of the Àger sub-basin (Barnolas et al., 2004).

\section{MATERIALS AND METHODS}

\section{Studied Material}

The studied material includes, first, the specimens from the type locality, Les Saleres, previously described by Crusafont-Pairó (1967) and Szalay (1971) and, second, unpublished dental material from this site. The first sample consists of a left mandible fragment preserving $\mathrm{P}_{3}, \mathrm{P}_{4}$, and two fragments of roots mesially located with respect to the $P_{3}$ (IPS-2543); two right isolated $M_{1}$ (IPS82793; IPS-82816); a left mandible fragment with $\mathrm{M}_{2}$ and $\mathrm{M}_{3}$ (IPS-1981, holotype) and a right mandible fragment with $M_{2}$ and $M_{3}$ (IPS-2541). The unpublished sample includes a left mandible fragment with the distal part of the $\mathrm{M}_{3}$ and part of the ramus mandibularis (IPS-82790); a right mandible fragment with $M_{3}$ (IPS-82795), and one right and one left mandible fragments with $\mathrm{M}_{2}$ (IPS-82794 and IPS-2542, respectively). One of these two latter specimens probably corresponds to the $M_{1}$ or $M_{2}$ referred by Crusafont-Pairó (1967) but not included in the work of Szalay (1971), but this cannot be affirmed due to the lack of illustrations of that molar. All the studied material is housed at Institut Català de Paleontologia Miquel Crusafont, ICP (Sabadell, Spain).

\section{Comparative Sample}

The material of Agerinia roselli from Les Saleres has been compared directly with the specimens of Agerinia sp. from Condé-en-Brie (France), Donrussellia gallica, Pronycticebus gaudryi and Protoadapis curvicuspidens, all housed in the collections of the Muséum National d'Histoire Naturelle (MNHN), Paris. It has also been compared with the material of Agerinia cf. roselli from Azillanet (France), belonging to the collections of 
the Université de Montpellier 2, in loan in the MNHN. It has also been compared with casts of Periconodon huerzeleri, Donrussellia magna, D. provincialis, Cantius eppsi, Europolemur klatti, Protoadapis ignoratus, Marcgodinotius indicus, and Asiadapis cambayensis, also stored in the MNHN. Finally, comparisons with Agerinia sp. from Casa Ramón (Spain), cf. Agerinia from Rians (France), Periconodon sp. from Eckfeld Maar (Germany), $P$. lemoinei, P. jaegeri, Donrussellia lusitanica, D. louisi, D. russelli, Darwinius masillae, Pronycticebus neglectus, Europolemur koenigswaldi, E. dunaifi, E. kelleri, Cantius savagei, Protoadapis angustidens, $P$. brachyrhynchus, $P$. weigelti, and $P$. muechelnensis are based on published data.

\section{Dental nomenclature, Measurements, Micrographs, and Radiographs}

The dental nomenclature used follows Szalay and Delson (1979). Measurements have been taken with an optic calliper "Nikon measuroscope 10" connected to a monitor "Nikon SC112", using the criteria described by Marigó et al. (2010). The height of $\mathrm{P}_{3}$ and $\mathrm{P}_{4}$ has been measured as the distance between the apex and the crown base observed in lingual view. Micrographs have been taken using the Environmental Scanning Electron Microscope (ESEM) at the Universitat de Barcelona. Body mass has been estimated on the basis of the equations for the $M_{1}$ and $M_{2}$ of prosimian proposed by Egi et al. (2004). Radiographs have been taken using a constant potential $X$-ray equipment "Yxlon", with different voltages $(50,55,60$, $65,70,75$, and $80 \mathrm{kV}$ ), at Centre de Restauració de Béns Mobles (Valldoreix, Barcelona).

\section{SYSTEMATIC PALAEONTOLOGY}

Order PRIMATES Linnaeus, 1758 Suborder STREPSIRRHINI Geoffroy Saint-Hilaire, 1812

Infraorder ADAPIFORMES Hoffstetter, 1977

Family NOTHARCTIDAE Trouessart, 1879

Subfamily CERCAMONIINAE Gingerich, 1975

Genus AGERINIA Crusafont-Pairó, 1973

Agerinia roselli (Crusafont-Pairó, 1967)

Figures 2, 3

\section{Original Diagnosis (Szalay, 1971)}

"The adapine adapid Agerina differs from all known species of Protoadapis in having $\mathrm{P}_{3}$ and $\mathrm{P}_{4}$ subequal in height, and in lacking a distinct, anteroposteriorly oriented cristid obliqua on $\mathrm{P}_{4}$ talonid. Unlike the trigonids of Protoadapis or Pronycticebus, those of Agerina are sealed off lingually by the union of the metaconid mesially and the paracristid distally. Although the paracristid is very low in Agerina, this crest invariably extends lingually almost to the limits of the metaconid, whereas in Pronycticebus the paracristid extends only midway on $\mathrm{M}_{1}$ and slightly more lingually on $\mathrm{M}_{2}$ and $\mathrm{M}_{3}$. Differences between Agerina and Adapis are most noticeable in the complete absence of a metastylid on the lower molars of the former. Agerina differs from Caenopithecus in having a larger metaconid on $\mathrm{P}_{4}$ and in lacking a metastylid and any traces of an entoconid. Talonid cusps of Agerina are generally less bulbous than those of Caenopithecus. Agerina differs from Pelycodus in lacking the distinct, cuspate paraconid on $M_{1}$ and in the generally less bulbous nature of the talonid cusps."

\section{Emended Diagnosis}

Medium-size cercamoniine. $\mathrm{P}_{3}$ and $\mathrm{P}_{4}$ subequal in height. $\mathrm{P}_{4}$, with well-developed protoconid, metaconid, and cristid obliqua, distinct paraconid, entoconid, and talonid basin. $M_{1}$ with a tiny paraconid; $\mathrm{M}_{2}$ and $\mathrm{M}_{3}$ without any trace of paraconid. Trigonid basin closed in all the three lower molars. Protocristid subperpendicular to the lingual and buccal borders in all molars. Short talonid basin with rounded outline in the $\mathrm{M}_{1}$ and $\mathrm{M}_{2}$.

Agerinia roselli differs from Periconodon in the presence of a marked metaconid in the $\mathrm{P}_{4}$ and the shorter and broader trigonid in the $\mathrm{M}_{1}$; it further differs from Periconodon jaegeri in the lack of enamel wrinkling. It differs from Darwinius masillae in the smaller size and the presence of a tiny paraconid in the $\mathrm{M}_{1}$. It can be distinguished from Donrussellia by the shorter trigonid and the smaller paraconid in the $M_{1}$ and by the absence of paraconid in the $M_{2}$ and $\mathrm{M}_{3}$. Agerinia roselli differs from Cantius in the much smaller size, the less inflated cuspids, the protocristid of the $M_{1}$ subperpendicular to the buccal and lingual borders and the lack of paraconid in the $\mathrm{M}_{2}$ and $\mathrm{M}_{3}$. It can be distinguished from Pronycticebus by the much smaller size; it further differs from $P$. gaudryi in the absence of paraconid in the $\mathrm{M}_{2}$ and $\mathrm{M}_{3}$. Agerinia roselli differs from Europolemur in the smaller size. Besides, it differs from $E$. kelleri in the presence of paraconid in the $M_{1}$ and from $E$. dunaifi in the closed and shorter trigonid in the $\mathrm{M}_{1}$ and $\mathrm{M}_{2}$. Agerinia roselli differs from Protoadapis in being smaller, in having $\mathrm{P}_{3}$ and $\mathrm{P}_{4}$ similar in height and in the less inflated cuspids in the lower molars. It differs from Asiadapis cambayensis in the well-developed metaconid in the $\mathrm{P}_{4}$ and in having the paraconid smaller in the $M_{1}$ and 

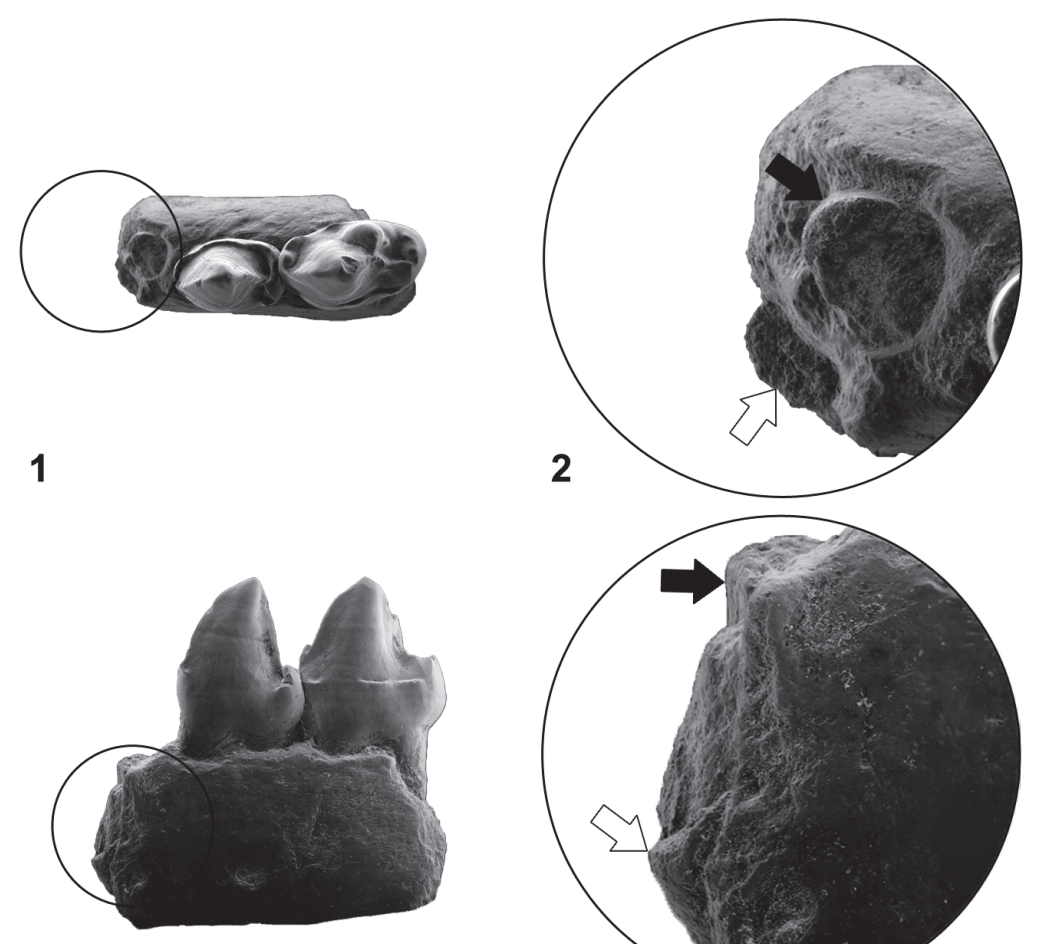

3
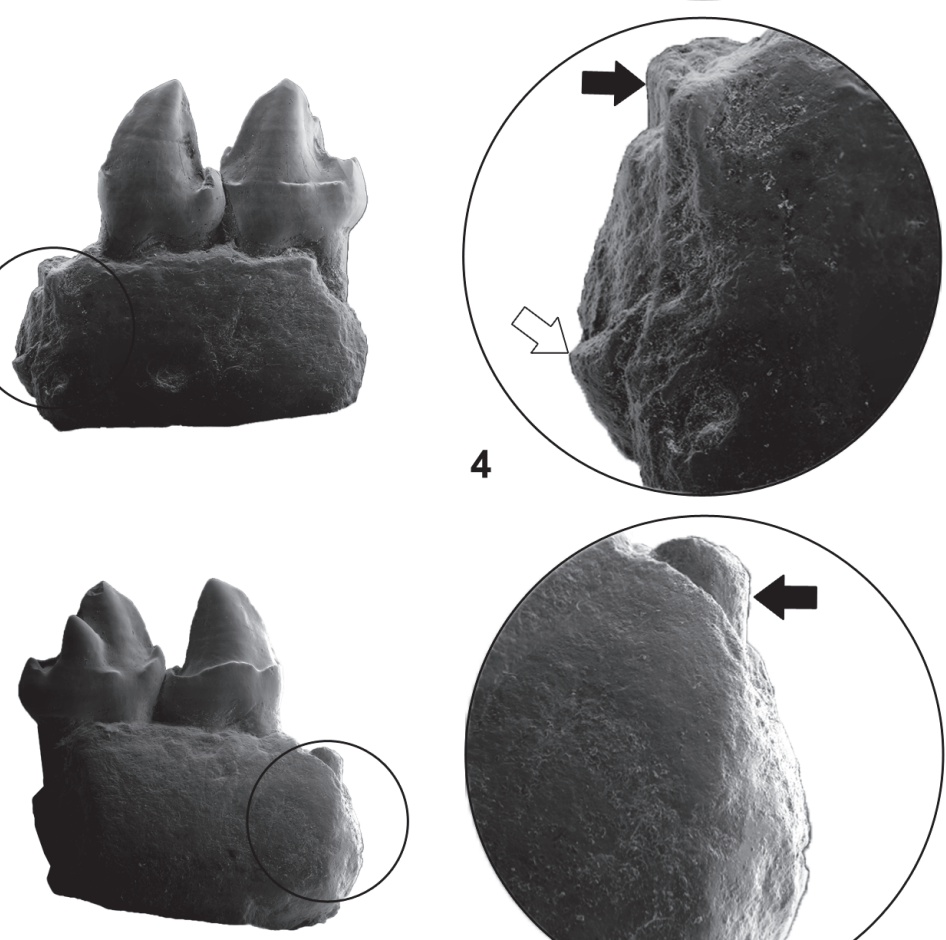

5
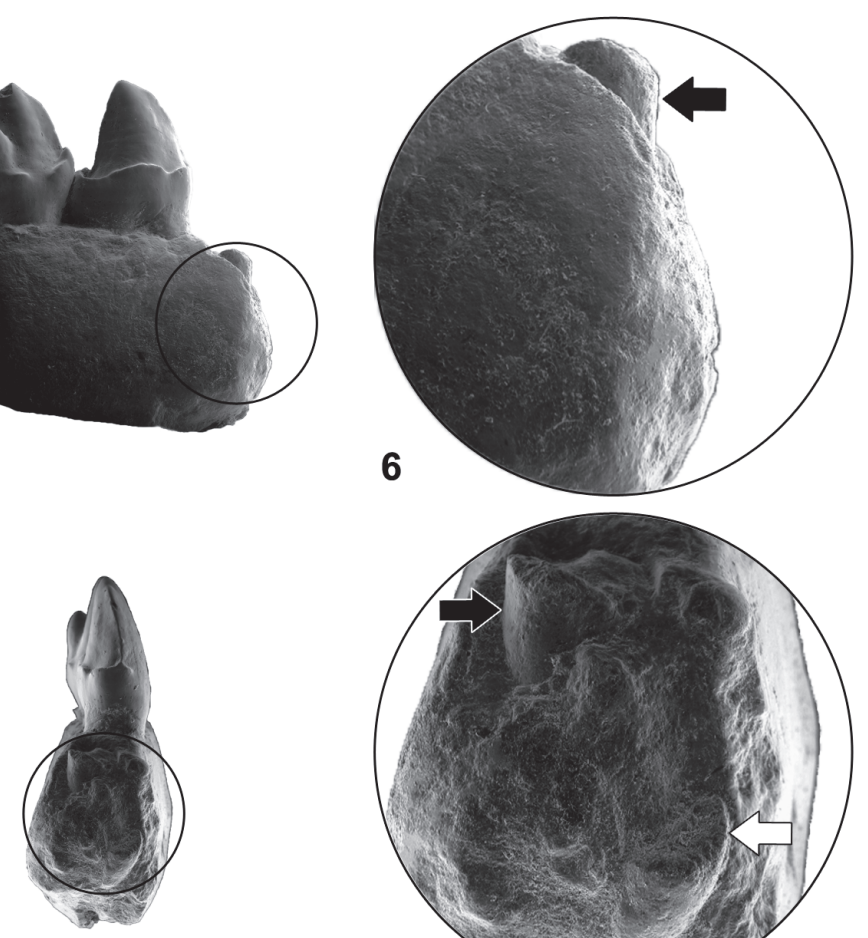

7

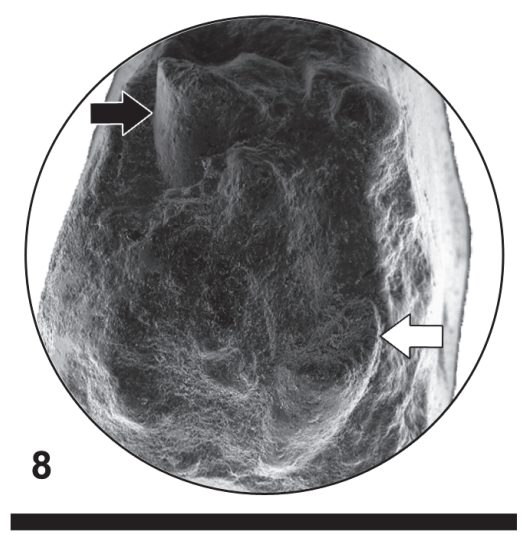

FIGURE 2. Agerinia roselli from Les Saleres. IPS-2543, left mandible fragment with $\mathrm{P}_{3}$ and $\mathrm{P}_{4}$ in occlusal (1), buccal (3), lingual (5), and mesial (7) views; enlarged images of mesial roots of the same specimen in occlusal (2), buccal (4), lingual (6), and mesial (8) views; white arrows indicate the position of the most mesial root; black arrows indicate the position of the root immediately mesial with respect to the $P_{3}$. Scale bar represents $3 \mathrm{~mm}$ in both cases. 


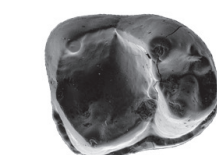

1

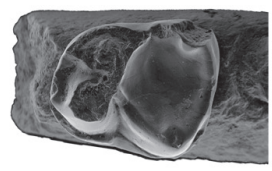

7

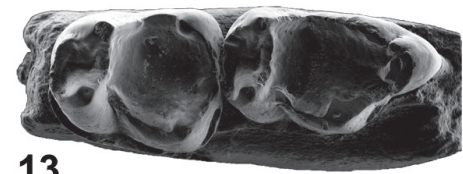

13

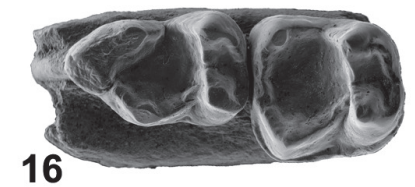

19
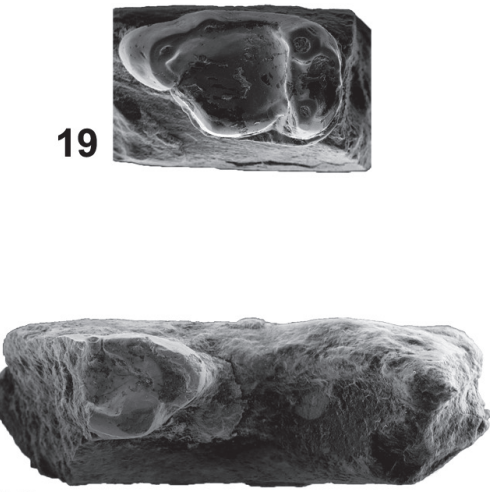

22

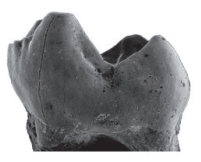

3

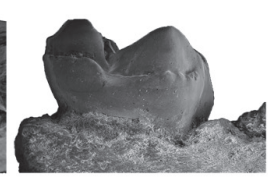

8

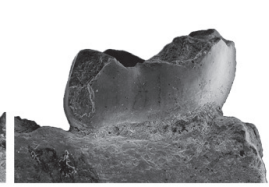

9

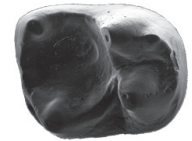

4

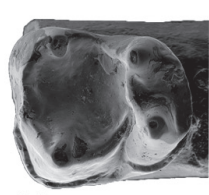

10

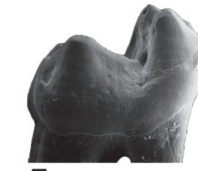

5

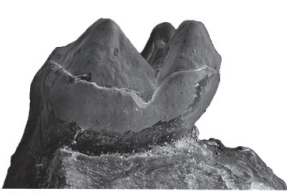

11

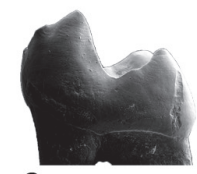

6

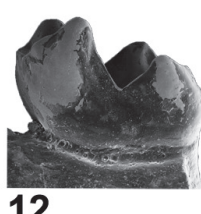

12
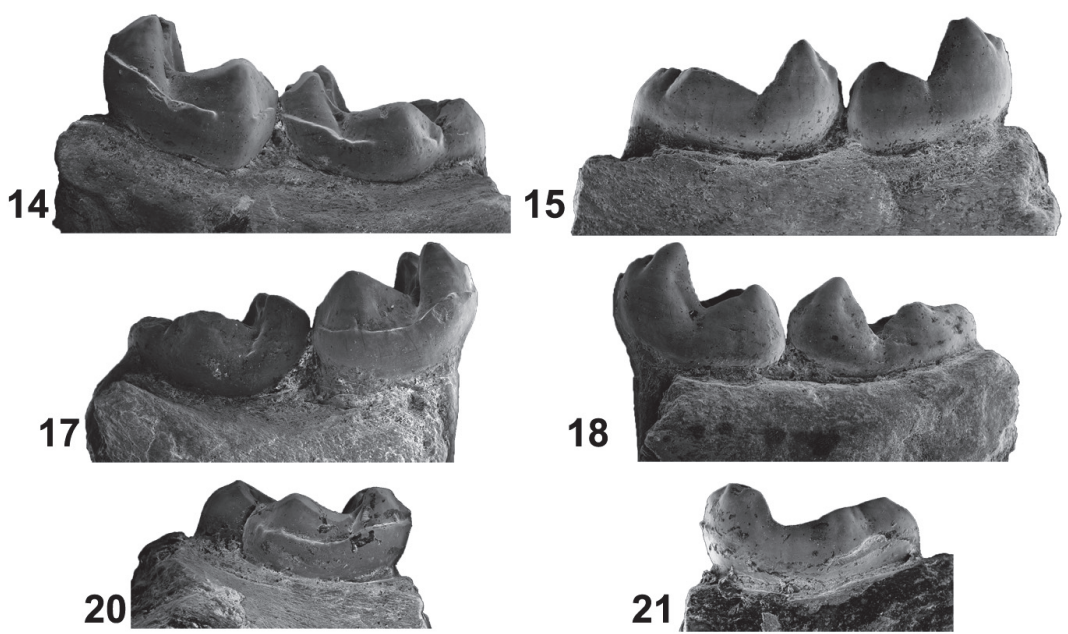

18
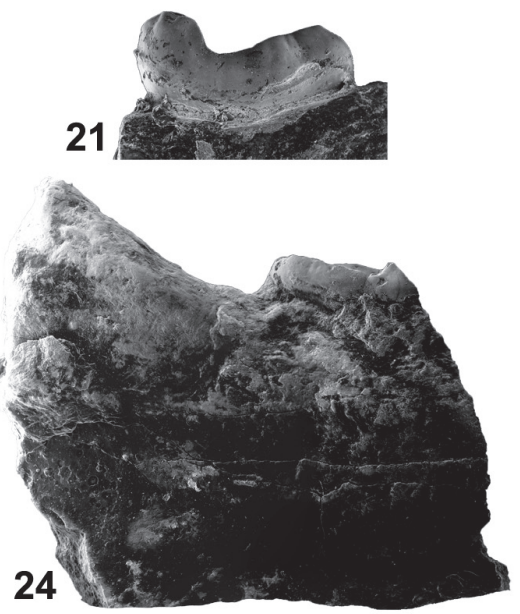

FIGURE 3. Agerinia roselli from Les Saleres. IPS-82793, isolated right $M_{1}$ in occlusal (1), buccal (2) and lingual (3) views. IPS-82816, isolated right $M_{1}$ in occlusal (4), buccal (5) and lingual (6) views. IPS-2542, left mandible fragment with $M_{2}$ in occlusal (7), buccal (8) and lingual (9) views. IPS-82794, right mandible fragment with $M_{2}$ in occlusal (10), buccal (11) and lingual (12) views. IPS-1981, holotype, left mandible fragment with $M_{2}$ and $M_{3}$ in occlusal (13), buccal (14) and lingual (15) views. IPS-2541, right mandible fragment with $M_{2}$ and $M_{3}$ in occlusal (16), buccal (17) and lingual (18) views. IPS-82795, right mandible fragment with $M_{3}$ in occlusal (19), buccal (20) and lingual (21) views. IPS82790 , left mandible fragment preserving part of the ramus mandibularis and a fragment of the $M_{3}$ in occlusal (22), buccal (23) and lingual (24) views. Scale bar represents $3 \mathrm{~mm}$.

absent in the $\mathrm{M}_{2}$ and $\mathrm{M}_{3}$. Agerinia roselli can be distinguished from Marcgodinotius indicus by its larger size, the presence of a paraconid and the more developed metaconid in the $\mathrm{P}_{4}$ and the closed trigonid in the $M_{1}$.

\section{Description}

Mandible. Some morphological traits of the mandible can be observed in specimens IPS-2543 and IPS-82790. The former specimen, bearing $P_{3}$ and $\mathrm{P}_{4}$, also preserves two root fragments of the ante- 
rior premolars. There is a root fragment in central position, placed mesially with respect to the $P_{3}$. In addition, in a more mesial position, the specimen preserves a small fragment of root strongly displaced towards the buccal border of the mandible. The assignation of these roots to single-rooted $P_{1}$ and $\mathrm{P}_{2}$ or to a double-rooted $\mathrm{P}_{2}$, is further analysed in the discussion. In addition, this mandible shows two mental foramina, oval shaped, and similar in size. The mesial mandibular foramen is located at the level of the root placed immediately mesial to the $\mathrm{P}_{3}$ and the distal mandibular foramen at the level of the distal root of the $P_{3}$. The specimen IPS82790 preserves the mesial part of the ramus mandibularis, which is robust and shows a well-marked masseteric fossa.

$\mathbf{P}_{3}$. It is clearly longer than wide. There is no paraconid. At the center of the tooth, there is a high and pointed protoconid with sharp paracristid and protocristid, both mesiodistally oriented. At the end of the protocristid, close to the distobuccal corner of the tooth, there is a small bulge that does not constitute a differentiated cuspid. There is a strong cingulid, starting at the mesial corner, occupying the lingual and distal borders, and reaching the distobuccal bulge. This cingulid encloses a well-differentiated basin on the distolingual part of the tooth. There are two roots.

$\mathbf{P}_{4}$. It is larger than the $P_{3}$, similar in height and with better developed cuspids. The protoconid is as high as in the $\mathrm{P}_{3}$ and has a sharp paracristid directed mesially; this cristid turns lingually near the base of the crown, reaching a small but distinct paraconid. There is a short cristid directed lingually from the paraconid, restricted to the mesiolingual corner of the tooth. The protoconid connects to the metaconid by a short protocristid, which shows a trigonid notch. The metaconid is well differentiated, inflated, and two-thirds the height of the protoconid. There is no premetacristid. The cristid obliqua reaches the trigonid wall at the level of the trigonid notch. At the distobuccal corner of the tooth, the cristid obliqua thickens, forming a minuscule hypoconid. There is a very short postcristid that connects the hypoconid to the entoconid, which is similar in size to the paraconid, and slightly higher than the hypoconid. There is a short preentocristid, which does not reach the metaconid, so the talonid basin is open lingually. The lingual cingulid is very weak and short, only observed on the middle of the lingual side. The buccal cingulid is also weak; it runs from the buccal base of the paraconid to the buccal base of hypoconid, but it is interrupted at the level of the protoconid apex. There are two roots.

$\mathbf{M}_{1}$. The two available isolated molars are here attributed to $M_{1}$ (see discussion for further details). The trigonid is slightly narrower than the talonid; in IPS-82816 this difference is less marked and the outline is more quadrate than in IPS-82793. The paracristid is curved and connects the protoconid to a minuscule paraconid, attached to the mesial side of the metaconid. The trigonid basin is deep and closed. The protoconid is placed in a faintly more mesial position than the metaconid, which is slightly higher. The protocristid, connecting protoconid and metaconid, is nearly straight and almost perpendicular to the lingual and buccal borders of the tooth. The cristid obliqua reaches the trigonid wall faintly buccally with respect to the trigonid notch. The talonid basin is closed, deep, and much longer than the trigonid. The cristid obliqua, postcristid, and preentocristid are slightly curved, thus giving a rounded aspect to the outline of the talonid. The hypoconid is slightly higher and more voluminous than the entoconid, which is placed in a faintly more distal position. A minuscule hypoconulid is observed in specimen IPS-82793. The buccal cingulid is very strong in IPS-82793 and barely marked in IPS-82816; it occupies the entire buccal border, from the mesial base of the protoconid to the distal base of the hypoconid.

$\mathbf{M}_{2}$. The trigonid width is variable: it is very narrow in IPS-1981, somewhat wider in IPS-82794 and in IPS-2542; and only slightly narrower than the talonid in IPS-2541. There is no paraconid. The paracristid surrounds the mesial side of the tooth, continues in a premetacristid and connects to the metaconid, closing a relatively deep trigonid basin. The protoconid and metaconid are similar in height; the former is placed in a slightly more mesial position. The protocristid, almost perpendicular to the buccal and mesial borders, connects the protoconid and metaconid. The cristid obliqua reaches the trigonid wall close to the trigonid notch. The talonid basin is closed, deep, and slightly wider than long. The hypoconid is higher than the entoconid and located in a slightly more mesial position. The postcristid is curved and, mainly at the middle of its length, it has a minuscule hypoconulid in all specimens except for IPS-2542. The buccal cingulid is strong; it runs from the mesial base of the protoconid to the level of the hypoconulid. This cingulid becomes thinner or even almost interrupted at the level of the hypoconid.

$\mathbf{M}_{3}$. There is no trace of paraconid. The paracristid starts at the protoconid, borders the mesial side of 
TABLE 1. Teeth measurements (in mm) of Agerinia roselli (Crusafont-Pairó, 1967) from Les Saleres.

\begin{tabular}{ccccc}
\hline Catalogue number & Tooth & Length & Width & Height \\
\hline IPS-2543 & $\mathrm{P}_{3}$ & 2.27 & 1.43 & 2.65 \\
& $\mathrm{P}_{4}$ & 2.77 & 1.70 & 2.66 \\
IPS-82793 & $\mathrm{M}_{1}$ & 3.24 & 2.72 & - \\
IPS-82816 & $\mathrm{M}_{1}$ & 3.24 & 2.50 & - \\
IPS-2542 & $\mathrm{M}_{2}$ & 3.26 & 2.61 & - \\
IPS-82794 & $\mathrm{M}_{2}$ & 3.51 & 3.06 & - \\
IPS-1981 & $\mathrm{M}_{2}$ & 3.31 & 2.66 & - \\
& $\mathrm{M}_{3}$ & 3.93 & 2.29 & - \\
IPS-2541 & $\mathrm{M}_{2}$ & 3.28 & 2.73 & - \\
& $\mathrm{M}_{3}$ & 3.24 & 2.11 & - \\
IPS-82790 & $\mathrm{M}_{3}$ & - & $\geq 1.97$ & - \\
IPS-82795 & $\mathrm{M}_{3}$ & 3.97 & 2.42 & - \\
\hline
\end{tabular}

the tooth, and continues in a premetacristid that reaches the metaconid, closing the trigonid. The trigonid basin is deep; it is relatively shorter and wider in IPS-2541 and IPS-82795 than in IPS1981. The protoconid is placed in a slightly more mesial position than the metaconid. The protocristid is nearly perpendicular to the mesial and buccal borders of the tooth, and shows a trigonid notch, more marked in IPS-2541 than in the rest of specimens. The cristid obliqua reaches the trigonid wall at the level of the protoconid, in a more buccal position than in the $M_{1}$ and $M_{2}$. The talonid basin is deep and longer than wide. The hypoconid is larger than the entoconid and placed in slightly more mesial position. The hypoconulid lobe is broad and well differentiated; it is placed in lingual position, closer to the entoconid than to the hypoconid. The preentocristid connects the entoconid to the metaconid in IPS-82795; IPS-1981 shows a shallow talonid notch close to the metaconid, whereas IPS-2541 and IPS-82790 display a deep talonid notch. The hypocristid is interrupted close to the base of the hypoconulid, showing in all specimens a well-marked notch. The buccal cingulid is strong in IPS-82795, weaker in IPS-1981, and almost not observable in IPS-2541. It starts at the mesial base of the protoconid and reaches the distal base of the hypoconid, being interrupted at the level of the hypoconid apex in IPS-1981. Specimen IPS-82795 shows a very weak mesial cingulid at the base of the metaconid.

\section{Measurements}

\section{See Table 1.}

\section{Comparisons}

Comparisons with other samples attributed to Agerinia. The specimens from Les Saleres have been compared with the material from Azillanet (France), assigned to Agerinia cf. roselli by Godinot $(1983,1998)$. The latter is larger than $A$. roselli; the difference in size is more evident in $M_{2}$ and $M_{3}$ than in $M_{1}$. Despite the resemblance in overall morphology, some differences can be observed. The $\mathrm{M}_{1}$ of Agerinia cf. roselli from Azillanet lacks the minuscule paraconid present in those from Les Saleres. The trigonid is longer in the lower molars of $A$. cf. roselli than in those of $A$. roselli, although this difference is more accentuated in the $M_{1}$. The cuspids are slightly more bulbous in $A$. cf. roselli than in $A$. roselli. The protocristid is more oblique in all the lower molars of $A$. cf. roselli than in $A$. roselli. Agerinia cf. roselli also has the protoconid in a more mesial position than the teeth from Les Saleres. The development of the buccal cingulid is similar in both samples (slightly stronger in the $M_{3}$ of $A$. cf. roselli from Azillanet).

Differences are obvious with the scarce material of Agerinia sp. from Casa Ramón (PeláezCampomanes, 1995). The main difference is size, with Agerinia sp. being clearly smaller than $A$. roselli from Les Saleres. In addition, some morphological differences are observed. The single $M_{1}$ from Casa Ramón only preserves the buccal part; it differs from the specimens of $A$. roselli in the shape of the paracristid, which forms an acute angle near the mesiobuccal corner of the tooth in Agerinia sp. The $\mathrm{M}_{2}$ of Agerinia sp. from Casa Ramón is relatively longer and narrower than those of $A$. roselli. The paracristid is lower in Agerinia sp. from Casa Ramón than in Agerinia roselli from Les 
Saleres. Finally, the protocristid is slightly more oblique to the buccal and lingual borders in Agerinia sp. than in A. roselli.

The material from Les Saleres has been also compared with the specimens of Agerinia sp. from Condé-en-Brie figured by Herbomel and Godinot (2011). The lower molars from this French locality share many similarities with $A$. roselli, but some differences exist that reinforce the idea that they can belong to a new, still undescribed species, as suggested by Herbomel and Godinot (2011). The main difference is size, with Agerinia sp. from Condé-enBrie being clearly larger. The trigonid is longer and narrower in the lower molars from Condé-en-Brie than in those from Les Saleres. In addition, the $M_{1}$ of Agerinia sp. from Condé-en-Brie differs from the specimens of $A$. roselli in the presence of a large paraconid and in the open trigonid basin, while in A. roselli the paraconid is very small and the premetacristid closes completely the trigonid basin. The $M_{1}$ from Condé-en-Brie shows slightly wrinkled enamel in the talonid, whereas no specimen from Les Saleres has enamel crenulation. The protocristid is clearly more oblique to the longitudinal axis of the tooth in the lower molars of Agerinia sp. than in those of $A$. roselli, especially in its buccal half. Moreover in $A$. roselli, the talonid basin of the $M_{1}$ and $\mathrm{M}_{2}$ is wider than long, whereas in Agerinia sp. from Condé en Brie it is longer than wide. In addition, according to the descriptions of Herbomel and Godinot (2011), some $\mathrm{M}_{2}$ of Agerinia sp. from Condé-en-Brie have a very small paraconid, which is absent in the all the $M_{2}$ from Les Saleres.

Finally, comparisons with the single $M_{2}$ from Rians assigned by Godinot (1983; 1998) to cf. Agerinia have been made. It shares some similarities with $A$. roselli such as the broad and deep talonid basin, despite that in RI 410 the talonid is slightly narrower than in $A$. roselli. Nevertheless, they show some clear differences, particularly the presence of a well-developed paraconid in the specimen from Rians. Moreover, the protocristid is more oblique to the lingual and buccal borders in the $\mathrm{M}_{2}$ from Rians than in $A$. roselli. In addition, the single tooth from Rians shows a marked distolingual expansion that is not observed in the molars from Les Saleres and a slightly less developed buccal cingulid.

In conclusion, Agerinia roselli shows several morphological traits that allow distinguishing this species from the others samples assigned to the genus Agerinia. Unfortunately, the material from other fossil sites is, in general terms, scarce and poorly preserved, preventing the erection of other species and the interpretation of the phylogenetic relationships between several samples. Probably, the detailed study of the material from Condé en Brie, only preliminarily studied (Herbomel and Godinot, 2011), will shed new light on the evolution of this genus. In addition, further fieldwork is needed to recover more material of this genus.

Comparisons with other Eurasian Notharctidae. Agerinia was interpreted by Gingerich (1977) as a synonym of Periconodon, but this opinion is not shared by most authorities, who consider Agerinia a valid genus (Szalay and Delson, 1979; Godinot, 1983, 1988, 2015; Gebo, 2002). Despite some similarities, the material of $A$. roselli from Les Saleres shows significant differences with Periconodon that support the existence of two separated genera. Only the species of Periconodon that include lower teeth allow comparison with $A$. roselli. Among them, Agerinia roselli is slightly larger than $P$. huerzeleri and similar in size to $P$. jaegeri. The only material of $P$. lemoinei allowing comparisons is the holotype, an $\mathrm{M}_{1}$ from Grauves described and figured by Gingerich (1977). According to this author, other isolated teeth from this French locality are also assignable to this species, but data about the size and morphology of these specimens are not published. The inclusion of this species in the genus Periconodon has been questioned by Godinot (1998). In any case, we have compared with the type of $P$. lemoinei, which is longer than the $\mathrm{M}_{1}$ of $A$. roselli and similar in width. Agerinia roselli also differs from the holotype of $P$. lemoinei in having the trigonid of the $\mathrm{M}_{1}$ lingually closed. The teeth of $A$. roselli are shorter but wider than those of Periconodon sp. from Eckfeld Maar (Franzen, 2004). Morphologically, Periconodon differs from Agerinia in having a weak metaconid in the $\mathrm{P}_{4}$, whereas in Agerinia this cuspid is well differentiated. In addition, Periconodon shows a longer and narrower trigonid in the $\mathrm{M}_{1}$ than Agerinia. Moreover, some $\mathrm{M}_{1}$ of Periconodon lack the small paraconid that is present in those of Agerinia. Besides these characters, $A$. roselli clearly differs from $P$. jaegeri because this latter species shows wrinkled enamel and a cristid starting in the metaconid and directed towards the centre of the trigonid that is absent in A. roselli.

Darwinius masillae is clearly larger than Agerinia roselli and very similar regarding the morphology of the $M_{1}$ and $M_{2}$ (Franzen et al., 2009): both species have the trigonid shorter and narrower than the talonid, a protocristid almost perpendicular to the buccal and lingual borders, and closed trigonid basins. Despite these similarities, clear differ- 
ences are observed, such as the presence of a tiny paraconid in the $\mathrm{M}_{1}$ of $A$. roselli that is absent in $D$. masillae. In addition, Darwinius shows a welldeveloped metastylid in the $M_{1}$, which is absent in Agerinia. The buccal cingulid is slightly more marked in Darwinius than in A. roselli. Regarding the premolars, if the two mesial root fragments of the specimen IPS-2543 correspond to singlerooted $\mathrm{P}_{1}$ and $\mathrm{P}_{2}, A$. roselli would differ from $D$. masillae in the number of premolars, since this latter lacks a $P_{1}$. If, on the contrary, the roots of the specimen from Les Saleres correspond to a double-rooted $\mathrm{P}_{2}, A$. roselli would be also different from $D$. masillae, because the specimen from Messel shows a single-rooted $P_{2}$. In both cases, therefore, the premolar arrangement of $D$. masillae would be more derived than that of $A$. roselli.

Donrussellia includes several species described from France $(D$. provincialis, $D$. gallica, D. magna, D. louisi, and D. russelli) and Portugal (D. lusitanica). Agerinia roselli is clearly larger than $D$. provincialis from Rians (Godinot, 1978), $D$. gallica from Avenay (Russell et al., 1967), $D$. lusitanica from Silveirinha (Estravís, 2000) and $D$. russelli from Avenay (Gingerich, 1977). On the contrary, it is smaller than $D$. louisi from Avenay (Gingerich, 1977) and D. magna from Palette (Godinot et al., 1987). Morphologically, clear differences exist between these two genera; the most remarkable one is the presence of a distinct paraconid in all the three lower molars of Donrussellia, whereas there is only a tiny cuspid in the $M_{1}$ of $A$. roselli. The trigonid of the $\mathrm{M}_{1}$ is shorter than the talonid in A. roselli, whereas in Donrusellia the trigonid is almost as long as the talonid. The trigonid basin in the lower molars of Donrussellia is shallow and generally open, whereas in A. roselli this basin is always quite deep and closed lingually. Moreover, $D$. lusitanica, $D$. provincialis, and $D$. magna have a well-developed hypoconulid in $\mathrm{M}_{1}$ and $\mathrm{M}_{2}$, whereas in $A$. roselli this cuspid is very reduced or absent. In the cases of $D$. russelli and $D$. louisi, comparisons are only possible with the $\mathrm{M}_{1}$ due to the scarcity of the available material; in any case, the presence of a large paraconid and a well-developed hypoconulid in both species (Gingerich, 1977) allows a clear distinction from $A$. roselli. In general terms, the buccal cingulid is more marked in A. roselli than in Donrussellia.

The genus Cantius is much larger than Agerinia. This genus includes several species recorded from North America and two forms from Europe, Cantius eppsi and Cantius savagei. The material from Les Saleres has been only compared in detail with the European species. Besides the clear difference in size with both species (Gingerich, 1977; Hooker, 2010), the $\mathrm{P}_{4}$ of $A$. roselli differs from that of $C$. eppsi in the presence of a distinct entoconid. In addition, the trigonid is broader and shallower in the molars of $C$. eppsi than in those of Agerinia, especially in the $M_{2}$ and $M_{3}$. The most obvious difference is the presence of a very well-developed paraconid in all the lower molars of $C$. eppsi (with the exception of some $M_{3}$ ) and in the $M_{1}$ of $C$. savagei, whereas in $A$. roselli only the $\mathrm{M}_{1}$ displays a very reduced paraconid. In addition, $C$. eppsi and $C$. savagei show more inflated cuspids than $A$. roselli. The protocristid has a more oblique orientation in the $\mathrm{M}_{1}$ of $C$. eppsi and $C$. savagei than in those of $A$. roselli. Furthermore, in the $M_{1}$ of $C$. savagei the talonid basin is shorter than in $A$. roselli, and the cristid obliqua reaches the trigonid wall at the level of the metaconid, whereas in A. roselli it reaches the level of the protoconid.

Concerning Pronycticebus gaudryi from Mermerlein in France (Grandidier, 1904; Le Gros Clark, 1934; Szalay, 1971), it is slightly larger than Agerinia roselli. In both species there is a small paraconid in the $\mathrm{P}_{4}$, but this premolar is more robust in $P$. gaudryi than in $A$. roselli. Pronycticebus gaudryi has a paraconid in all the lower molars, decreasing in size from $M_{1}$ to $M_{3}$, whereas in $A$. roselli only the $M_{1}$ displays a minuscule paraconid. The trigonid basin is shallow, mesiodistally elongated and lingually open in $P$. gaudryi whereas in $A$. roselli it is deep, short and closed; moreover, this basin is clearly narrower in $P$. gaudryi. The cuspids of $P$. gaudryi are slightly more bulbous than those of $A$. roselli. The orientation of the protocristid is one of the main differences between these species: oblique to the buccal and lingual sides in $P$. gaudryi and almost perpendicular to them in $A$. roselli. The cristid obliqua is clearly more curved in $A$. roselli than in $P$. gaudryi. The buccal cingulid is, in general, more marked in $A$. roselli than in $P$. gaudryi. Regarding Pronycticebus neglectus, described by Thalmann, Haubold and Martin (1989), this species was later ascribed to the genus Godinotia by Franzen (2000b). Godinotia neglecta can be clearly distinguished from Agerinia roselli, mainly by its notably larger size.

There are four described species of Europolemur: E. koenigswaldi and E. kelleri from Messel (Franzen, 1987, 2000a), E. dunaifi from Bouxwiller (Godinot, 1988), and E. klatti from Geiseltal (Thalman, 1994). All of them are clearly larger than Agerinia roselli. The presence of paraconid in the molars of Europolemur is variable: E. kelleri lacks 
this cuspid in all the lower molars; $E$. koenigswaldi shows a tiny paraconid in the $\mathrm{M}_{1}$; $E$. dunaifi shows generally a small paraconid in $\mathrm{M}_{1}$ but usually lacks this cuspid in the $\mathrm{M}_{2}$ (in $A$. roselli a tiny paraconid is only observed in the $M_{1}$ ). Moreover, the trigonid is much shorter in A. roselli than in E. dunaifi, especially in the $M_{1}$. In addition, the trigonid is open in the $M_{1}$ and $M_{2}$ in $E$. dunaifi, whereas it is closed in A. roselli. Another clear difference is the orientation of the protocristid, which is more oblique to the buccal and lingual sides in E. dunaifi. Furthermore, in the latter species the cristid obliqua reaches the trigonid wall more lingually than in $A$. roselli.

According to Godinot (2015), the genus Protoadapis includes the species $P$. curvicuspidens, $P$. ignoratus, $P$. angustidens, $P$. (Cercamonius) brachyrhynchus, $P$. weigelti, and $P$. muechelnensis, all of them poorly known. These six species are clearly different from $A$. roselli, being much larger and having more inflated cuspids in the lower molars. The $\mathrm{P}_{3}$ is clearly higher than the $\mathrm{P}_{4}$ in Protoadapis, whereas in $A$. roselli these two premolars are subequal in height. Besides, some Protoadapis species like $P$. curvicuspidens have a distinct paraconid in the $\mathrm{M}_{1}$ and $\mathrm{M}_{2}$, while in $A$. roselli there is a tiny cuspid only in the $M_{1}$. The trigonid basin of Protoadapis is larger than in $A$. roselli and sometimes open lingually. The talonid basin is relatively larger and deeper in A. roselli than in Protoadapis.

There are several similarities between Asiadapis cambayensis from Vastan Mine in India (Rose et al., 2007) and Agerinia roselli, such as the presence of a small paraconid in the $\mathrm{P}_{4}$, the broad and short trigonid basin in the $\mathrm{M}_{2}$ and $\mathrm{M}_{3}$, or the relatively wide, short, and deep talonid basin of the molars. However, there are significant differences between these species. The premolars of $A$. cambayensis are slightly larger than those of $A$. roselli, especially the $\mathrm{P}_{3}$. However, the molars are slightly smaller in A. cambayensis than in A. roselli. The metaconid of the $\mathrm{P}_{4}$ is well-developed in $A$. roselli, whereas it is absent or small in $A$. cambayensis. Moreover, the $\mathrm{P}_{3}$ in $A$. cambayensis is higher than the $\mathrm{P}_{4}$, whereas in $A$. roselli they are similar in height. Regarding the molars, A. cambayensis shows a well-marked paraconid in the $M_{1}$ and a small cuspid in some $M_{2}$ and $M_{3}$ (see Rose et al., 2009) whereas in $A$. roselli the paraconid is faint in the $M_{1}$ and absent in the $M_{2}$ and $M_{3}$. The cristid obliqua is curved in A. roselli (and therefore the talonid basin has a somewhat rounded outline), and straight in A. cambayensis. In general, the buccal cingulid in A. roselli is stronger than in A. cambayensis.

Marcgodinotius indicus from Vastan Mine (Bajpai et al., 2005) shares some features with $A$. roselli such as a closed and deep trigonid basin in the $M_{2}$ and $M_{3}$ or a deep talonid basin in all the lower molars. However, they differ in some traits such as the larger size of $A$. roselli. The $\mathrm{P}_{4}$ of $M$. indicus lacks a paraconid and only one specimen shows a very small metaconid, whereas in $A$. roselli there is a distinct paraconid and a prominent metaconid. In the lower molars, the trigonid is slightly longer in $M$. indicus than in A. roselli. The trigonid basin is open lingually in the $\mathrm{M}_{1}$ of $M$. indicus whereas it is closed in $A$. roselli. Moreover, $M$. indicus shows a small paraconid in some $\mathrm{M}_{1}$ and $\mathrm{M}_{2}$, while in $A$. roselli a minuscule paraconid is only present in the $M_{1}$. The protocristid in the $M_{1}$ and some $\mathrm{M}_{2}$ of $M$. indicus is slightly more oblique to the lingual and buccal sides than in $A$. roselli. The difference in width between trigonid and talonid is much more marked in A. roselli than in M. indicus. The cristid obliqua, postcristid, and preentocristid of $A$. roselli are more curved than those of $M$. indicus, and therefore the outline of the talonid basin is more rounded. The buccal cingulid is more marked in $A$. roselli than in $M$. indicus.

\section{Body Mass Estimation}

The body mass of Agerinia roselli was already estimated by Conroy (1987), who calculated a weight between 376 and $466 \mathrm{~g}$. However, that study was based only on the area of the $M_{1}$. A later work by Egi et al. (2004) considered other dental elements for body mass estimation and, in addition, excluded larger-sized primates from the equations, thus making them more suitable for the estimation of body mass in small- and mediumsized fossil primates. Therefore, a new estimation of the body size of $A$. roselli has been developed following this latter work.

According to Egi et al. (2004), the first and second molars are the best elements for body mass estimations in small samples of fossil primates (the correlation coefficient between the area of these dental elements and the body mass is very high in living prosimians: $R=0.971$ for $M_{1}$ and $\mathrm{R}=0.986$ for $\mathrm{M}_{2}$ ). Following these authors, the body mass of Agerinia roselli has been estimated based on the area (mesiodistal length $x$ buccolingual width) of the two available $M_{1}$ and the four available $M_{2}$. Using the $M_{1}$ and $M_{2}$ prosimian equations of Egi et al. (2004), the body mass of $A$. roselli falls within the range from 650 to $725 \mathrm{~g}$ for the $M_{1}$ (Fig- 


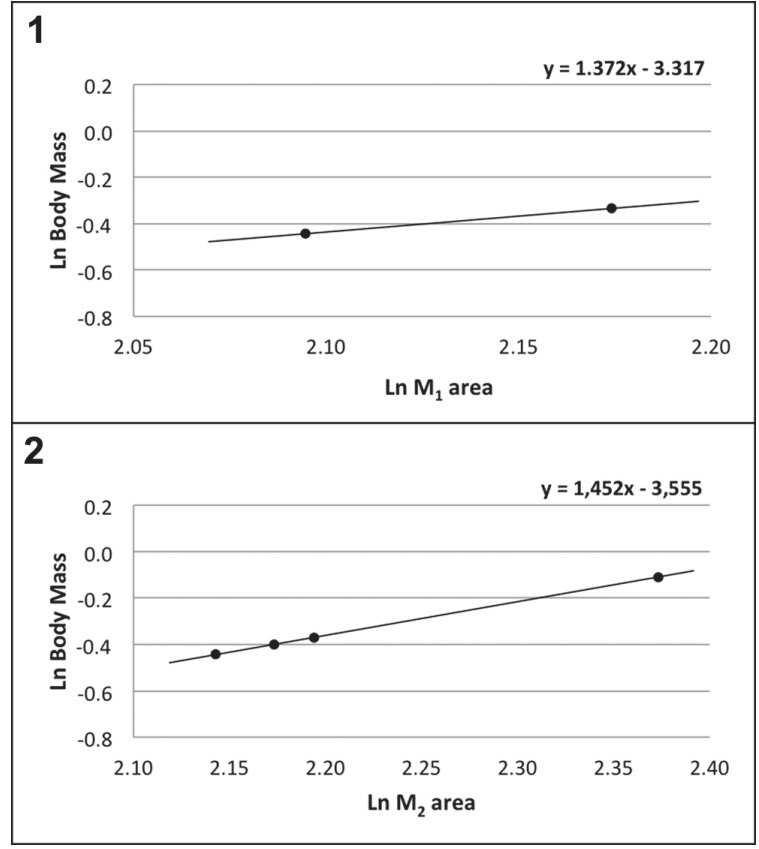

FIGURE 4. Body mass estimate regressions for Agerinia roselli. 1, derived from the area of the $\mathrm{M}_{1} ; 2$, derived from the area of the $\mathrm{M}_{2}$. Black dots represent different molars of $A$. roselli. Black line indicates regression based on extant prosimian data from Egi et al. (2004).

ure 4.1) and from 644 to $900 \mathrm{~g}$ for the $\mathrm{M}_{2}$ (Figure 4.2). Therefore, the body mass of $A$. roselli can be estimated to range from 650 to $900 \mathrm{~g}$ approximately, similar to that of living strepsirrhines such as the Sunda slow loris (Nycticebus coucang) or the Ankarana sportive lemur (Lepilemur ankaranensis).

\section{DISCUSSION}

The Spanish site Les Saleres, type locality of Agerinia roselli, has yielded the most abundant material attributed to this genus up to now, including the previously published material and the new remains described here for the first time. The description of the entire hypodigm has improved the knowledge about the dental anatomy of this species, including some features that have not been observed until now.

One of the most important characters previously undescribed for this species is the presence of two roots mesial with respect to the $\mathrm{P}_{3}$ observed in the mandible fragment IPS-2543, which could belong to single-rooted $P_{1}$ and $P_{2}$ or to a doublerooted $P_{2}$. Since the presence of four premolars has previously been interpreted as a primitive character for adapiforms, the fact that $A$. roselli could present single-rooted $\mathrm{P}_{1}$ and $\mathrm{P}_{2}$ would represent $a$ solid argument for distinguishing it from other adapiforms such as Darwinius masillae. Moreover, the single-rooted $\mathrm{P}_{2}$ would represent an advanced character in comparison with other cercamoniines such as Donrussellia, Asiadapis, or Pronycticebus gaudryi, all of them having double-rooted $\mathrm{P}_{2}$. If this was the case, the $P_{1}$ would be markedly shifted towards the buccal side of the mandible, occupying a much more buccal position than the rest of the premolars. Such an arrangement of the premolars has been described in other early primates such as Teilhardina, which shows a reduction of the size of the $\mathrm{P}_{1}$ and a displacement of this premolar towards the buccal side from older to younger species, being this premolar lost in the most recent forms (Smith et al., 2006).

If the two roots correspond to a double-rooted $P_{2}$, it would present a very oblique orientation with respect to the mesiodistal axis of the mandible. In this case, it would be similar to other cercamonines like Mazateronodon endemicus that has imbricated third and fourth premolars obliquely oriented (Marigó et al., 2010) or Marcgodinotius indicus, which shows an oblique double-rooted $\mathrm{P}_{2}$ (Rose et al., 2009). However, the obliquity of the $P_{2}$ would be even more marked in $A$. roselli than in $M$. indicus.

In order to discern between these two possibilities, several radiographs of the specimen IPS2543 have been made, with different voltages ranging from 50 to $80 \mathrm{kV}$. The radiograph in which the image is clearer, corresponding to a voltage of $75 \mathrm{kV}$, is presented in Figure 5. This radiograph clearly shows the roots of $\mathrm{P}_{3}$ and $\mathrm{P}_{4}$, which in both cases are long and divergent, but the two mesial roots cannot be distinguished, probably due to the preservation of the specimen. However, the space between the mesial root of the $\mathrm{P}_{3}$ and the most mesial fragment of root, the end of which is directed backwards and reaches a very low position (Figure 5.2), seems to be not enough to house another root of the same length (as it would be expected if the two fragments of roots correspond to a double-rooted $P_{2}$, with two roots divergent and similar in length, like those of the $P_{3}$ and $P_{4}$ ). It seems more likely that these fragments correspond to single-rooted $P_{1}$ and $P_{2}$, with roughly parallel (not divergent) roots, being the former slightly longer than the latter.

In any case, none of these two possibilities can be accepted or refused, and more, well-pre- 


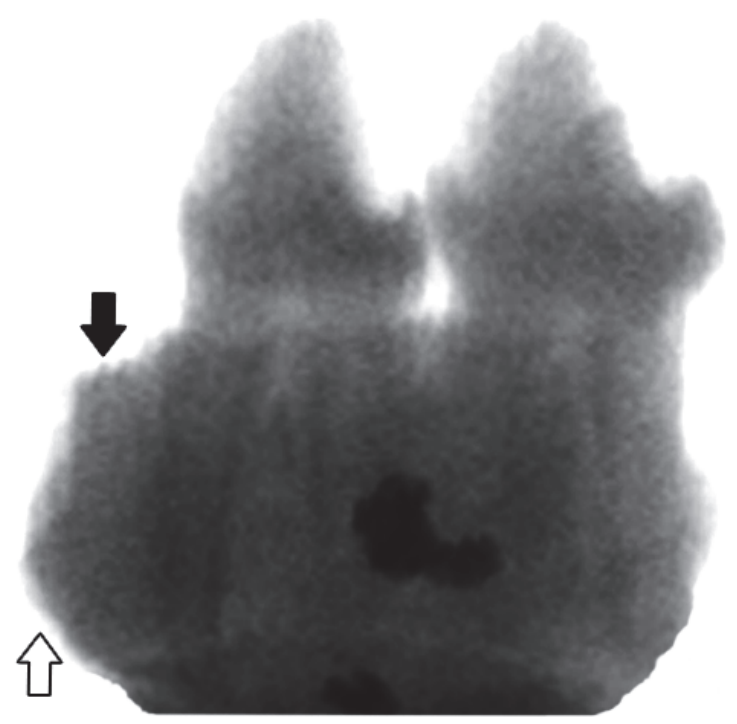

1

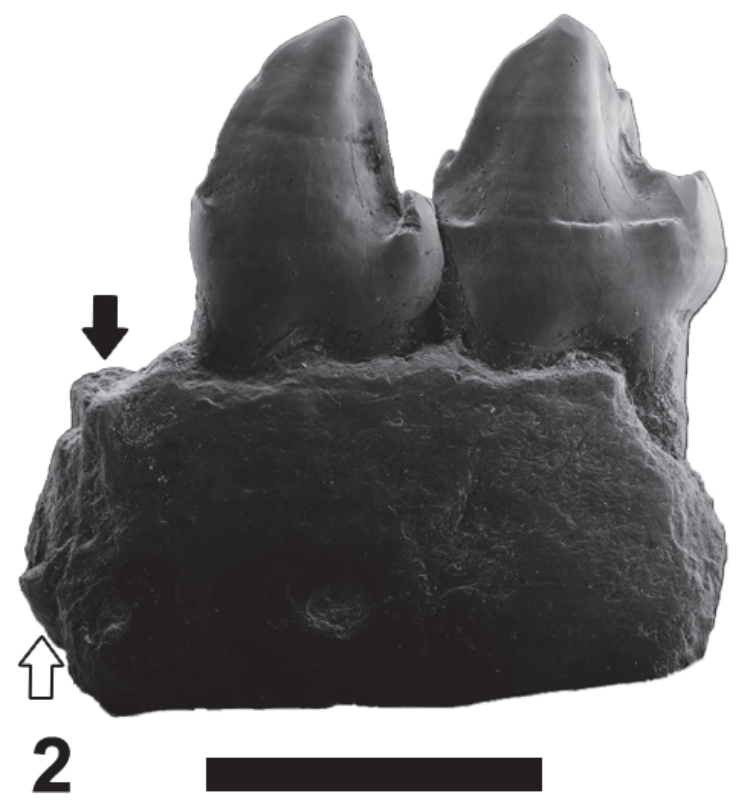

FIGURE 5. Radiograph represented with inverted colours (1) and ESEM micrograph (2) of the left mandible fragment of Agerinia roselli (IPS-2543) in buccal view. White arrows indicate the position of the most mesial root; black arrows indicate the position of the root immediately mesial with respect to the $\mathrm{P}_{3}$. Scale bars represent $3 \mathrm{~mm}$.

served material will be necessary to confirm the number of premolars of $A$. roselli. However, the presence of single-rooted $P_{1}$ and $P_{2}$ seem to be more plausible, because if the two roots correspond to a double-rooted $\mathrm{P}_{2}$, it would present an unusual, extremely oblique orientation, very different to the mesiodistal alignment of $\mathrm{P}_{3}$ and $\mathrm{P}_{4}$.

Similarly, the morphology of the $\mathrm{P}_{4}$ was not correctly described in previous works. The detailed observation of this premolar has led to the description of very small but distinct entoconid and hypoconid and a well-developed cristid obliqua, elements that were not depicted until now. In fact, the lack of a cristid obliqua in the $\mathrm{P}_{4}$ was one of the criteria listed by Szalay (1971) in his generic diagnosis of Agerinia, but, as shown in Figure 2.1, this cristid is clearly distinct in the only known $\mathrm{P}_{4}$ of $A$. roselli. Summarizing, the $\mathrm{P}_{4}$ of this species shows better-differentiated cuspids than described by previous authors.

Regarding the lower molars, the redescription of the material from Les Saleres has also highlighted some features that were not described until now. Particularly, according to previous works (Crusafont-Pairó, 1967; Szalay, 1971; Szalay and Delson, 1979; Godinot, 2015) all the lower molars of Agerinia were characterized by the complete absence of a paraconid. Nevertheless, the detailed observation of the lower molars of $A$. roselli from Les Saleres has allowed distinguishing a very small paraconid in two specimens (IPS-82816 and 82793), here interpreted as $M_{1}$. This interpretation is reinforced by the fact that the specimens IPS1891, 2541, 2542, and 82794, preserving their original position in the mandible and thus clearly identified as $\mathrm{M}_{2}$, lack any trace of paraconid. This way, we propose the presence or absence of this small paraconid as the most reliable criterion for differentiating first and second lower molars when they are found isolated. Szalay (1971) used the length of the trigonid to distinguish these two elements, based on the fact that, like in many other primates, the trigonid is progressively shorter from $M_{1}$ to $M_{3}$. However, we have observed certain variability in the length of the trigonid in the $M_{2}$ from Les Saleres. Among the four undoubtedly identified $\mathrm{M}_{2}$, specimens IPS-2541 and 82794 display a very short and wide trigonid, whereas IPS-1891 and 2542 show a relatively long and narrow basin. Moreover, the presence of a minuscule hypoconulid in some $M_{1}$ and $M_{2}$ was not noted in the descriptions made by Szalay (1971).

Concerning the phylogenetic affinities of Agerinia, Herbomel and Godinot (2011) suggested that it could be very close to Darwinius although, as stated by these authors, these interpretations are 
tentative and must be tested with more detailed analyses of the teeth of $D$. masillae, as well as with further descriptions of still unpublished material of Agerinia from the Paris Basin. Our detailed study of the material of $A$. roselli from Les Saleres confirms the resemblance in overall morphology with Darwinius, although clear differences also exist. The scarcity of material of Agerinia roselli and, especially, the lack of upper teeth hinder a more precise analysis of the dental morphology of this species. Therefore, further fieldwork allowing the recovery of additional material is necessary for improving the knowledge about this species and clarifying its relationships with other Adapiformes.

\section{CONCLUSIONS}

New material of Agerinia roselli from its type locality, Les Saleres, has been described. In addition, the sample from this site published by Crusafont-Pairó (1967) and Szalay (1971) has been carefully redescribed, since some inaccuracies were noted in previous studies of this species. This new description is accompanied by more accurate dental measurements and high-resolution images of all the available teeth from Les Saleres. An emended diagnosis is provided, emphasizing some traits such as the $P_{3}$ and $P_{4}$ subequal in height, the $\mathrm{P}_{4}$ with well-developed cuspids and crests, lower molars with short talonid basins and protocristid subperpendicular to the lingual and buccal borders, and paraconid very small in the $M_{1}$ and absent in the $M_{2}$ and $M_{3}$. The presence of two root fragments in a mesial position with respect to the $P_{3}$ could indicate either the existence of singlerooted $P_{1}$ and $P_{2}$ or the presence of a very obliquely oriented double-rooted $\mathrm{P}_{2}$. More material would be necessary to confirm the number of premolars of this species.

Among the most significant characters of Agerinia roselli, the minuscule paraconid in the $M_{1}$ has been identified in this study for the first time. Indeed, the presence of a distinct paraconid on the $M_{1}$ is proposed as the most reliable criterion to discern $M_{1}$ from $M_{2}$ when they are isolated. Other criteria used for distinguishing $M_{1}$ from $M_{2}$, particularly the length of the trigonid, have been demonstrated to be less consistent due to the high intraspecific variability. Finally, the body mass estimation made for this species, based on the area of the $M_{1}$ and $M_{2}$, indicates a weight ranging from 650 to $900 \mathrm{~g}$ approximately, similar to that of the extant Nycticebus coucang or Lepilemur ankaranensis and larger than interpreted in previous studies.
Summarizing, this work delivers new valuable data on the species Agerinia roselli and highlights its differences with other Eocene Adapiformes. However, the dental anatomy of this species is still not well known, mainly due to the lack of upper teeth. Further studies, involving new fieldwork and allowing the recovery of additional material, will surely improve the knowledge about this primate, its paleobiology, and its phylogenetic relationships.

\section{ACKNOWLEDGEMENTS}

We are deeply indebted to Dr. M. Godinot, Dr. E. Herbomel, and the rest of the staff of the Muséum National d'Histoire Naturelle, Paris, for their help and assistance when visiting their collections. We also thank Dr. B. Marandat (Université Montpellier 2) for his valuable comments and for providing essential literature for the development of this work. We want to thank Dr. J. Rosell (Universitat Autònoma de Barcelona) for providing very useful data about the Àger area, B. Moncunill-Solé (Institut Català de Paleontologia Miquel Crusafont) for her help with body mass estimation, and $E$. Gual (Centre de Restauració de Béns Mobles), for her kind assistance with the radiographs. We finally thank the handling editor A. Bush, and two anonymous reviewers for their constructive comments that greatly improved the manuscript.

This study has been supported by the projects "El registro fósil de primates de la Península Ibérica durante el Cenozoico: paleobiología, biocronología y contexto paleoambiental" (CGL201454373-P), Ministerio de Economía y Competitividad, Spanish Government, 'Estudi dels primats i faunes associades del Paleogen de Catalunya' (2014/100604), Generalitat de Catalunya, and the research group 'Grup de Recerca Consolidat Paleoprimatologia i paleontologia humana PIPH' (2014 SGR 416, GRC), Generalitat de Catalunya. J.F.-G. has been financied by the predoctoral scholarship BES-2012-052951 and the brief stay scholarship EEBB-I-14-08986 (Ministerio de Economía y Competitividad, Spanish Government). J.M. has been financed by the Fondation Fyssen.

\section{REFERENCES}

Antunes, M.T., Casanovas, M.L., Cuesta, M.A., Checa, L., Santafé, J.V., and Agustí, J. 1997. Eocene mammals from Iberian Peninsula. In Aguilar, J.P., Legendre, S., and Michaux, J. (eds.), Actes du Congrès BiochroM'97. Mémoires et Travaux de l'Ecole Pratique des Hautes Etudes, Institut de Montpellier, 21:337-352. 
Badiola, A., Checa, L., Cuesta, M.A., Quer, R., Hooker, J.J., and Astibia, H. 2009. The role of new Iberian finds in understanding European Eocene mammalian paleobiogeography. Geologica Acta, 7:243-258.

Bajpai, S., Kapur, V.V., Thewissen, J.G.M., Das, D.P., Tiwari, B.N., Sharma, R., and Saravanan N. 2005. Early Eocene primates from Vastan Lignite Mine, Gujarat, western India. Journal of the Palaeontological Society of India, 50:43-54.

Barnolas, A., Payros, A., Samsó, J.M., Serra-Kiel, J., and Tosquella, J. 2004. La Cuenca Surpirenaica desde el llerdiense medio al Priaboniense, p. 313320. In Vera, J.A. (ed.), Geología de España. SGEIGME, Madrid.

BiochroM'97. 1997. Synthèses et tableaux de corrélations. In Aguilar, J.P., Legendre, S., and Michaux, J. (eds.), Actes du Congrès BiochroM'97. Mémoires et Travaux de l'Ecole Pratique des Hautes Etudes, Institut de Montpellier, 21:769-805.

Checa, L. 1995. Los perisodáctilos (Ungulata, Mammalia) del Eoceno catalán. Unpublished PhD Thesis, University of Barcelona, Spain.

Conroy, G.C. 1987. Problems of body-weight estimation in fossil primates. International Journal of Primatology, 8:115-137.

Crusafont-Pairó, M. 1967. Sur quelques prosimiens de l'Eocène de la zone préaxiale pyrénaïque et un essai provisoire de reclassification. Problèmes actuels de Paléntologie - Évolution des Vertébrés. Colloques Internationaux du Centre National de la Recherche Scientifique, 163:611-632.

Crusafont-Pairó, M. 1973. El nombre genérico Agerinia sustituyendo a Agerina. Acta Geológica Hispánica, 8:150.

Crusafont-Pairó, M. and Golpe-Posse. J.M. 1975. Les prosimiens de l'Éocène de la région préaxiale pyrénaïque. II: Adapidae. Problèmes actuels de Paléntologie - Évolution des Vertébrés. Colloques Internationaux du Centre National de la Recherche Scientifique, 218:852-860.

Crusafont-Pairó, M. and Rosell-Sanuy, J., 1966. Primera datación de los tramos superiores del Eoceno continental de la Cuenca de Ager (Provincia de Lérida). Notas y Comunicaciones del Instituto Geológico y Minero de España, 83:79-92.

Egi, N., Takai, M., Shigehara, N., and Tsubamoto, T. 2004. Body mass estimates for Eocene eosimiid and amphipithecid primates using prosimian and anthropoid scaling models. International Journal of Primatology, 25:211-236.

Estravís, C. 2000. Nuevos mamíferos del Eoceno inferior de Silveirinha (Baixo Mondego, Portugal). Coloquios de Paleontología, 51:281-311.

Femenias-Gual, J., Marigó, J., Minwer-Barakat, R., and Moyà-Solà, S. 2014. First remains of Euprimates from from Masia de l'Hereuet (early Eocene, Catalonia, Spain), p. 57. In Delfino, M., Carnevale, G. and Pavia, M. (eds.), Abstract Book and Field Trip Guide of the XII Annual Meeting of the European Associa- tion of Vertebrate Palaeontologists. Museo Regionale di Scienze Naturali, Regione Piemonte, Torino.

Femenias-Gual, J., Marigó, J., Minwer-Barakat, R., and Moyà-Solà, S. 2015. First postcranial material assigned to Agerinia roselli (Primates, Adapiformes) from Les Saleres (early Eocene, Catalonia, Spain) [abstract]. American Journal of Physical Anthropology, 156:131-132.

Franzen, J.L. 1987. Ein neuer primate aus dem mitteleozän der grube Messel (Deutschland, S.- Hessen). Courier Forschungs-Institut Senckenberg, 91:151187.

Franzen, J.L. 2000a. Europolemur kelleri n. sp. von Messel und ein nachtrag zu Europolemur koenigswaldi (Mammalia, Primates, Notharctidae, Cercamoniinae). Senckenbergiana Lethaea, 80:275-287.

Franzen, J.L. 2000b. Der sechste Messel-Primate (Mammalia, Primates, Notharctidae, Cercamoniinae). Senckenbergiana Lethaea, 80:289-303.

Franzen, J.L. 2004. First fossil primates from Eckfeld Maar, middle Eocene (Eifel, Germany). Eclogae Geologicae Helvetia, 97:213-220.

Franzen, J.L., Gingerich, P.D., Habersetzer, J., Hurum, J.H., Koenigswald, W.v., and Smith, B.H. 2009. Complete Primate Skeleton from the middle Eocene of Messel in Germany: Morphology and Paleobiology. PLoS One, 4:e5723.

Gebo, D.L. 2002. Adapiformes: Phylogeny and Adaptation, p. 21-43. In Hartwig, W.C. (ed.), The primate Fossil Record. Cambridge University Press, Cambridge.

Gebo, D.L., Smith, T., and Dagosto, M. 2012. New postcranial elements for the earliest Eocene fossil primate Teilhardina belgica. Journal of Human Evolution, 63:205-218.

Gebo, D.L., Smith, R., Dagosto, M., and Smith, T. 2015. Additional postcranial elements of Teilhardina belgica: The oldest European primate. American Journal of Physical Anthropology, 156:388-406.

Geoffroy Saint-Hilaire, É. 1812. Tableau des quadrumanes. I. Ordre Quadrumanes. Annales Muséum National d'Histoire Naturelle Paris, 19:85-122.

Gingerich, P.D. 1975. A new genus of Adapidae (Mammalia, Primates) from the late Eocene of southern France, and its significance for the origin of higher primates. Contributions from the Museum of Paleontology, University of Michigan, 24:163-170.

Gingerich, P.D. 1976. Cranial anatomy and evolution of early Tertiary Plesiadapidae (Mammalia, Primates). University of Michigan Papers on Paleontology, 15:1140.

Gingerich, P.D. 1977. New Species of Eocene Primates and the Phylogeny of European Adapidae. Folia Primatologica, 28:60-80.

Godinot, M. 1978. Un nouvel Adapidé (primate) de l'Éocène inférieur de Provence. Comptes Rendus de l'Académie des Sciences de Paris, Série $D$, 286:1869-1872. 
Godinot, M. 1981. Les mammifères de Rians (Éocène inférieur, Provence). Palaeovertebrata 10:43-126.

Godinot, M. 1983. Contribution à l'étude des primates paleogènes d'Europe-systématique, locomotion. Unpublished PhD Thesis, Université des Sciences et Techniques du Languedoc, Montpellier, France.

Godinot, M. 1988. Les primates adapidés de Bouxwiller (Eocène moyen, Alsace) et leur apport à la compréhension de la faune de Messel et à l'évolution des Anchomomyini. Courier Forschungs-Institut Senckenberg, 107:383-407.

Godinot, M. 1998. A summary of adapiform systematics and phylogeny. Folia Primatologica, 69:218-249.

Godinot, M. 2015. Fossil Record of the Primates from the Paleocene to the Oligocene, p. 1137-1259. In Henke, W. and Tattersall, I. (eds.), Handbook of Paleoanthropology. Springer-Verlag Berlin Heidelberg, Berlin.

Godinot, M., Crochet, J.Y., Hartengerger, J.L., LangeBadré, B., Russell, D.E., and Sigé, B. 1987. Nouvelles données sur les mammifères de Palette (Eocène infériur, Provence). Münchner Geowissenschaftliche Abhandlungen, Reihe A, Geologie und Paläontologie, 10:273-288.

Grandidier, G. 1904. Un nouveau lémurien fossile de France, le Pronycticebus gaudryi. Bulletin du Muséum National d'Histoire Naturelle, Paris, 10:9-13.

Herbomel, E. and Godinot, M. 2011. A new species of Agerinia (Primates, Adapiformes) and its bearing on the phylogenetic affinities of Darwinius masillae, $\mathrm{p}$. 80-81. In Lehmann, T. and Schaal, S.F.K. (eds.), The world at the time of Messel: Puzzles in palaeobiology, palaeoenvironment and the history of early primates. 22nd International Senckenberg Conference. 15th19th November 2011 Frankfurt am Main. Conference volume. Senckenberg Gesellschaft für Naturforschung, Frankfurt am Main.

Hoffstetter, R. 1977. Phylogénie des Primates: confrontation des résultats obtenus par les diverses voies d'approche du problème. Bulletins et Mémoires de la Société d'Anthropologie de Paris, 4:327-346.

Hooker, J.J. 1996. Mammalian biostratigraphy across the Paleocene-Eocene boundary in the Paris, London and Belgian basins. Geological Society London Special Publications, 101:205-218.

Hooker, J.J. 2010. The mammal fauna of the early Eocene Blackheath Formation of Abbey Wood, London. Monograph of the Palaeontographical Society, London, 164:1-162.

Hooker, J.J. 2012. A new omomyid primate from the earliest Eocene of southern England: First phase of microchoerine evolution. Acta Palaeontologica Polonica, 57:449-462.

Le Gros Clark. W.F. 1934. On the skull structure of Pronycticebus gaudryi. Proceedings of the Zoological Society of London, 1:19-27.

Linnaeus, C. 1758. Systema Naturae per Regna Tria Naturae, Secundum Classes, Ordines, Genera, Spe- cies, cum Characteribus, Differentiis, Synonymis, Locis (tenth edition). Laurentii Salvii, Stockholm.

Marandat, B. 1991. Mammifères de l'llerdien moyen (Éocène inférieur) des Corbières et du Minervois (Bas-Languedoc, France). Systématique, Biostratigraphie, Corrélations. Palaeovertebrata, 20:55-144.

Marigó, J., Minwer-Barakat, R., and Moyà-Solà, S. 2010. New Anchomomyini (Adapoidea, Primates) from the Mazaterón middle Eocene locality (Almazán Basin, Soria, Spain). Journal of Human Evolution, 58:353361.

Marigó, J., Minwer-Barakat, R., and Moyà-Solà, S. 2011. New Anchomomys (Adapoidea, Primates) from the Robiacian (middle Eocene) of northeastern Spain. Taxonomic and evolutionary implications. Journal of Human Evolution, 60:665-672.

Marigó, J., Minwer-Barakat, R., and Moyà-Solà, S. 2013. Nievesia sossisensis, a new anchomomyin (Adapiformes, Primates) from the early late Eocene of the southern Pyrenees (Catalonia, Spain). Journal of Human Evolution, 64:473-485.

Marigó, J., Minwer-Barakat, R., Moyà-Solà, S., and López-Torres, S. 2012. First record of Plesiadapiformes (Primates, Mammalia) from Spain. Journal of Human Evolution, 62:429-433.

Marigó, J., Roig, I., Seiffert, E.R., Moyà-Solà, S., and Boyer, D.M. 2016. Astragalar and calcaneal morphology of the middle Eocene primate Anchomomys frontanyensis (Anchomomyini): implications for early primate evolution. Journal of Human Evolution, 91:122-143.

Marigó, J., Susanna, I., Minwer-Barakat, R., MadurellMalapeira, J., Moyà-Solà, S., Casanovas-Vilar, I., Robles, J.M., and Alba, D.M. 2014. The primate fossil record in the Iberian Peninsula. Journal of Iberian Geology, 40:179-211.

Minwer-Barakat, R., Marigó, J., and Moyà-Solà, S. 2010. A New Species of Pseudoloris (Omomyidae, Primates) from the middle Eocene of Sant Jaume de Frontanyà (Eastern Pyrenees, Spain). American Journal of Physical Anthropology, 143:92-99.

Minwer-Barakat, R., Marigó, J., and Moyà-Solà, S. 2012. Pseudoloris cuestai, a new microchoerine (Omomyidae, Primates) from the middle Eocene from the lberian Peninsula. Journal of Vertebrate Paleontology, 32:407-418.

Minwer-Barakat, R., Marigó, J., and Moyà-Solà, S. 2013a. Redescription and designation of a neotype for Pseudoloris reguanti Crusafont-Pairó, 1967, an Eocene primate from the Iberian Peninsula. American Journal of Physical Anthropology, 151:245-251.

Minwer-Barakat, R., Marigó, J., and Moyà-Solà, S. 2015a. Necrolemur anadoni, a new species of Microchoerinae (Omomyidae, Primates) from the middle Eocene of Sant Jaume de Frontanyà (Pyrenees, Northeastern Spain). American Journal of Physical Anthropology, 158:730-744.

Minwer-Barakat, R., Badiola, A., Marigó, J., and MoyàSolà, S. 2013b. First record of the genus Microchoe- 
rus (Omomyidae, Primates) in the western Iberian Peninsula and its palaeobiogeographic implications. Journal of Human Evolution, 65:313-321.

Minwer-Barakat, R., Marigó, J., Femenias-Gual, J., and Moyà-Solà, S. 2015b. New material of Pseudoloris parvulus (Microchoerinae, Omomyidae, Primates) from the late Eocene of Sossís (Northeastern Spain) and its implications for the evolution of Pseudoloris. Journal of Human Evolution, 83, 74-90.

Peláez-Campomanes, P. 1995. Primates and rodents from the middle Eocene of Casa Ramón (Huesca, Spain). Proceedings of the Koninklijke Nederlandse Akademie van Wetenschappen, 98:291-312.

Rose, K.D., Rana, R.S., Sahni, A., Kumar, K., Missiaen, P., Singh, L., and Smith, T. 2009. Early Eocene primates from Gujarat, India. Journal of Human Evolution, 56:366-404.

Rose, K.D., Rana, R.S., Sahni, A., and Smith, T. 2007. A new adapoid primate from the early Eocene of India. Contributions from the Museum of Paleontology, University of Michigan, 31:379-385.

Rosell-Sanuy, J. and Llompart-Díaz, C. 1988. Guia geològica del Montsec $i$ de la vall d'Àger. Centre Excursionista Catalunya, Editorial Montblanc-Martín, Barcelona.
Russell, D.E., Louis, P., and Savage, D.E. 1967. Primates of the French early Eocene. University of California Publications in Geological Sciences, 73:1-46.

Smith, T., Rose, K.D., and Gingerich, P.D. 2006. Rapid Asia-Europe-North America geographic dispersal of earliest Eocene primate Teilhardina during the Paleocene-Eocene thermal maximum. Proceedings of the National Academy of Sciences of the United States of America, 103:11223-11227.

Szalay, F.S. 1971. The European adapid primates Agerina and Pronycticebus. American Museum Novitates, 2466:1-18.

Szalay, F.S. and Delson, E. 1979. Evolutionary History of the Primates. Academic Press, New York.

Thalmann, U. 1994. Die Primaten aus dem eozänen Geiseltal bei Halle/Saale (Deutschland). Courier Forschungs-Institut Senckenberg, 175:1-161.

Thalmann, U., Haubold. H., and Martin, R.D. 1989. Pronycticebus neglectus - An almost complete adapid primate specimen from the Geiseltal (GDR). Palaeovertebrata 19:115-130.

Trouessart, E.L. 1879. Catalogue des mammifères vivants et fossiles. Revue et Magasin de Zoologie Pure et Appliquée, Paris, 7:223-230. 